\title{
Factors that Present Obstacles to the Learning of Quran: A Study based on Polonnaruwa District in Sri Lanka
}

\author{
Nasrin Muhammadu Ibrahim ${ }^{1} \quad$ Ahmed Sarjoon Razick $^{2 *} \quad$ Iqbal Saujan $^{3} \quad$ Samila Begum Mohomed Sali $^{4}$ \\ 1.Department of Islamic Studies, South Eastern University of Sri Lanka, PO box 51049, 94/A, \\ Pudukkudiiruppuwa, Thambala, Polonnaruwa, Sri Lanka \\ 2.Department of Islamic Studies, South Eastern University of Sri Lanka, PO box 91554, 33/1, Walawwathe, \\ Bakinigahawela, Bibile, Sri Lanka \\ 3.Department of Islamic Studies, South Eastern University of Sri Lanka, PO box 32354, 67 Beach Road, \\ palamunai, Sri Lanka \\ 4.Department of Islamic Studies, South Eastern University of Sri Lanka, School Road, PO box 4100 Sornapuri, \\ Adampan, Mannar, Sri Lanka
}

\begin{abstract}
Al-Quran is the divine revelation to Prophet Muhammad (PBUH), which started with the word "Iqra". Quranic education is an obligation to every Muslim. It is the responsibility of parents and teachers to help the new generation with Quranic learning so they become true Muslims and better humankind. Today, children and younger generations have more opportunities to learn the Quran properly, as compared to middle-aged people who do not have such opportunities even if they are interested in learning; Polonnaruwa district in Sri Lanka is no exception. In this study, we discovered the challenges that are faced by middle-aged people in learning the Holy Quran. This is a qualitative research. The key tool used in this study was a structured interview, which was participated by 40 middle aged people in Polonnaruwa. According to the results, it was found that the challenges faced by the participants include the lack of understanding on the importance of the Quran, the growing hatred toward Muslim "Alims", inadequate teaching with a proper method to recite the Quran and the failure to teach the Quran with proper guidance. Such are the reasons for the middle-aged people not being able to recite the Quran properly at present, even though they had attended the madrassa at a young age. In terms of gender, it was found that females are more interested in Quranic learning than males. Factors namely the lack of formally trained teacher and the reluctance of middle-aged people in participating the Quranic lesson have been identified as the most critical challenges that hinder Quranic learning among the middle-aged people despite their desire to learn. Based on these findings, it is suggested that the training and courses related to Quranic learning specially for middle-aged people be made necessary for them by the local mosques and Sri Lankan Muslim Cultural and Religious Affairs Department. In addition, the "Alims" and "Alimahs", who are graduated from Arabic colleges should come forward to teach the Quran to these middle-aged people.
\end{abstract}

Keywords: Obstacle to learning the Quran, learningof Al Quran, Quran madrassa, Middle-aged People

DOI: $10.7176 /$ RHSS/11-13-04

Publication date:June $30^{\text {th }} 2021$

\section{Introduction}

The Quran is a scripture that was gradually bestowed upon the Prophet Muhammad (PBUH) by almighty Allah through His angel, Jibreel. The Quran is the last of many scriptures sent down by Allah to the Messengers, starting from Adam (SAW) to Prophet Muhammad (PBUH); the Quran is also regarded as a proof of the prophethood of Prophet Muhammad (PBUH). It has been mentioned in the verses of the holy Quran that "Nor does he speak from [his own] inclination, It is not but a revelation revealed, Taught to him by one intense in strength" (Al-Quran 53:2-5). Prophet Muhammad (PBUH) taught the Quran to his companions for 23 years, from the age of 40 until his death.

The Quranic Verses taught by the Prophet were preserved by his companions through memorization and the writing on dried clay plates, palm leaves, animal skins, and bones. After the death of the Prophet, during the reign of Abubakr, all chapters of the Quran which were written and memorized under the observation of Zaid bin Thabit were compiled. Later, during the reign of 'Uthman, the Quran which was originally recited in 7 languages was completely compiled and copied in one language (Hadith Buhari- 4987). The Quran is organized based on a set of sounds. It was verbally taught to others by the Prophet based on the sound of the syllables. Unlike other written texts, the Quranic verses were delivered in the same way of one giving advice to the others. Verses are repeated many times as a reminder to people.

The Quran provides all the guidance related to Aqaid, Risalat and Ma'd, which are essential for human life. The Quran teaches humankind to discern the good from evil, and that to perform the good deeds and abstain from committing evil doings. The one who recites the Quran will be rewarded in abundantly, and the Quran guides human so they changes for the better and lead a fulfilling life.

The prophet (PBUH) developed five foundations of Al-Quran teaching and learning, which his companions 
and subsequent generations have continued to follow until now. Tilawah (fluency in recitation), Tafahum, and Tafsir (knowing and understanding the meaning) Tatbiq (appreciation and application of teaching in everyday life), Tahfiz (memorization of verses for practice and recitation of during prayer), and Taranum (recitation of Quran with a good voice and tone). Unfortunately, most teachers and students lack the ability to grasps these five foundations completely (Che Noh., Hussein., Ghani., Suhid, 2013).

When Mother Aisha (Radi-Allahu anha) was asked about the virtues of the Prophet, she replied, "Their characteristics were the Quran itself." The Companions who were with him also pursued the learning of Quran on day to day basis. When Imam Al-Banna once made a remark in regard to the carelessness of people in pursuing the Quran learning: "People were locked in a darkened room and clashed with the furniture and other things in the room without any light. None of them tried to turn on the light in the room. Similarly, in today's world, people forget the Quran". On the other hand, the Great Poet of Germany, Kade, described the Quran as "The gravitational power of the Quran makes us attractive. Surely the Quran fascinates those who read it."

Many scholars have expressed their views on the teaching of the Quran. One of them is that the Quran must be taught by a qualified teacher (Al Qari, 1998). Without a proper guidance from the experts, a person will not be able to read the Quran properly. A teacher who can recite the Quran fluently and smoothly, that is articulating every letter from its articulation point and giving the letter its rightful and due characteristics, is considered as a model teacher who focuses on al-Quran recitations (Al-Qassali, 1993). A good teaching is essential from the elementary to the advanced learning level (al-Qassali, 1980). That is why it is necessary to teach the Quran in the proper manner.

It is obligatory for every Muslim to learn the Quran. The Quran teaches human on how to live in this world and the duties of humankind toward the Creator and His creations; therefore it is important for humankind to practice the teachings in the Quran. We can see that today's environment is conducive for children and youth to learn Quran properly. Parents are capable of providing the necessary tools at home for children to continue learning, memorizing and revising the Quranic lessons taught at madrassa. Polonnaruwa district in Sri Lanka is no exception. It is very common for parents to encourage their children to learn the Quran.

Children and younger generations have more opportunities to learn the Quran, while middle- aged people rarely have such opportunities to do so. The middle-aged people are facing many challenges in learning the Quran, even if they are interested in the learning. There are many opportunities made available for children and the younger generation to learn the Holy Quran. However, there is no proper platform available for those who want to learn the Quran at later age - whether it was due to failure to learn the Quran at the early age or those who had the opportunity to do so but were not able to learn it properly. This research focused on the challenges faced in Quran learning among the middle-aged people.

Typically, the middle-aged people are faced with many difficulties that include being unable to deliver the verses of the Quran with meaning during daily prayers and having problem with the Tajweed when reciting the Quran. This comprehensive study was carefully conducted with the principle aim to identify the key factors that hinder the middle-aged people from learning the Quran.

\section{Research Methodology}

The study was carried out based on the primary data. Tambalai, Sungavila, Divulanai, and Manikkampitiya areas in the Polonnaruwa district were chosen for this study. A total of 20 males and females who did not attend the Quranic learning at madrassa at an early age were randomly selected and another sample of 40 males and females who went to the madrassas for Quranic learning was also selected and examined. The data was obtained via a structured interview and analyzed using the thematic content analysis method; the results are discussed.

\section{Literature review}

Mohd Aderi., Ab. Halim Tamuri., Khadijah Abd Razak., Suhid Asmawati (2014). The Study of Quranic Teaching and Learning: United Kingdom Experience: This research studied on the establishment of Muslim education in the United Kingdom focusing on Quranic teaching in Quranic education conducted in the United Kingdom. The research also discussed in detail the challenges in establishing Quranic education in the United Kingdom efficiently.

Tedi Supriyadi., J. Julia (2018). The Problem of Students in Reading the Quran: A Reflective-Critical Treatment through Action Research: This research suggested that it is obligatory to learn and teach the Quran, focusing on the development of the indicators in regard to recitation of the Quran. The paper evaluated the different aspects of Quranic learning and teaching and modes of encouragement for people to recite the Quran. There are six stages of Quran learning proposed in the research: drawing a diagram for reciting the Quran; categorizing groups for learning the Quran; teaching to recite the Quran; bringing up the habit of reciting the Quran; memorizing, testing and strengthening the ability to recite the Quran; and the final examination Quran recitation. These 6 stages were analysed in the study.

Nur Hannah Saari, Cila Umat, Kamarul Shukri Mat Teh (2012). Factors Affecting the Learning of the 
Holy Quran among severely and Profoundly Hearing-Impaired Children with a Cochlear Implant: This study focused on 14 boys of two age group: 5 to 10 year-old; and 8 to 15 year-old. Data for the study were collected in the form of audio record. The investigation was carried out by recording the recitation of verses from the Quran. The findings demonstrate that the study self-factors, parental factors, and teaching-related factors are influencing the quality of Quran recitation.

Mohn Aderi Che Noh, Katni, Yaumil Hatoya, Syarifan Nurjan, Rohmadi (2020). Examining Teaching and Learning of Quran: Empirical Research of Islamic School of Ma'arif Al Mukarom Ponorogo East Java Indonesia: This research examined the challenges faced by teachers in teaching the Quran. Data for the study were obtained from 100 teachers in two schools. It was found that the main challenges faced by the teachers are centred on the administrative and management, deficiency in the understanding of the art of teaching, and various behavioural spheres.

The above-mentioned research articles on Quranic learning have generally involved children and school students. No study has been conducted on the need for middle-aged people to learn the Quran and the challenges faced by these group of people in learning the Quran. Therefore, this research was conducted to bridge this particular gap in the literature, whereby challenges faced by the middle-aged people in learning the Quran were identified.

\section{Results and Discussion}

For this study, 20 male and female students who did not attend the Quran madrassa at the early age were according to the purposive sampling method. In addition, a total of 40 students consist of 20 males and 20 females, who went to the madrassa and tried to learn the Quran properly were also selected for this study. In total, this research collected 60 responses as samples for further analysis. The collected data from the structured interview were analysed and the results are discussed in this paper.

a. Contributing factors for not attending Quran madrassa in adolescence

The reasons for not attending Quran madrassa were investigated based on the responses from the 20 people who had not attended any Quranic learning at the madrassa. The responses are discussed in the following subsections. 4.1.1 The importance of the Quran is not realized

All participants, males and females responded that none of them realized the importance of learning the Quran at their early age. Also mentioned in the responses, parents and guardians had simply asked them to attend madrassa and recite the Quran, without giving proper awareness about the importance of Quranic education.

\subsubsection{Hatred toward the "Alims" (Who are teaching Quran)}

Responses from nine males and seven females expressed their impression about the "Alims" someone with a cane in his hand, ready to punish the student even for a small mistake; unfortunately, the impression was sometimes proven true. Such impression created a mentality among the respondents that they would be punished by the "Alim" if they had gone for the Quranic lessons; as a result, they fear and hatred toward the "Alims" become the factor that they avoided attending Quranic classes at the madrassa.

4.1.3 Poverty

Poverty was one of the most important factors that prevent Quran learning at young age according to the eight male and six female respondents. Most of the "Alims" have been running the Quran lessons at madrassa for profit; therefore, poverty becomes a barrier for some people to attend Quranic lessons at the madrassa as payment is required.

\subsubsection{Parents did not send their children to madrassa}

Another factor preventing people from attending the Quranic lesson at early age is the failure of parents in sending their children to madrassa for the lessons, as responded by 5 male and 3 female participants. Investigation found out that the parents had not realized the importance of the Quran and did not come from a Quran-learning background. Therefore, the parents failed to realize the importance of having their children learning the Quran.

4.1.5 More attention was given to worldly things than to learning at the madrassa

Giving more attention on worldly matters than going to madrassa was also identified as a factor that prevents the learning of Quran at an early age according to the two male respondents; none of the female agreed with this factor. Nevertheless, going to the paddy-fields with their father or family members, fishing, pet breeding (pigeon, myna, parrot) have been their priority as compared to attending the madrassa.

\subsection{Reasons for not being able to recite the Quran in a systematic manner despite attending the early- age Quranic lesson at madrassa}

The reasons for inability to recite the Quran in a systematic manner (Tajweed) despite receiving early education in Quranic study at madrassa were identified and discussed in the following subsections. The data were collected from 40 selected male and female participants and analyzed.

\subsubsection{Inadequate awareness about the importance of Tajweed in Quran recitation}

The inability of the teachers to properly teach the rules in reciting the Quran was agreed by all respondents as the 
main factor affecting the quality of their Quran recitation. They responded that the teaching of Quran at madrassa did not properly highlight the rules and systems in Quran recitation at the time. Moreover, it was mentioned that if the student recited an ain to the "Alim" every day, the day would be completed if the "Alim" signed the specified ain. Besides, no teaching activities had been carried out to properly teach students about Quran recitation. Most of the "Alims" of that time were from the same background so they too were not properly educated in the laws of reciting the Quran.

\subsubsection{The Quran is not taught with proper guidance}

Both male and female participants responded that the lack of proper guidance in the teaching of Quran had greatly affected the quality of their Quran recitation. Most of the "Alims" at the time were more eager to finish the lesson within the specified duration rather than providing in-depth knowledge about the Quran. In addition to no explain given about the merits of reciting the Quran, the parents at the time also did not provide any awareness as much as the parents nowadays do. Lack of encouragement to recite the Quran was also highlighted in the responses as one of the factors affecting the quality of their Quran recitation.

\subsubsection{The importance of the Quran has not been realized since childhood}

Responses from 15 male and 19 female participants mentioned that the importance of the Quran has not been properly instilled since childhood. Rather, the respondents regarded attending the Quranic lesson at madrassa as a routine, where they get to catch up with friends and play games with them. As a result, they failed to realize the importance of Quranic learning.

\subsubsection{Lack of knowledge about Quran among parents}

Responses from 17 male and 14 female participants agreed that lack of knowledge about Quran among parents hinder the children from learning the right way to recite the Quran. According to the respondents, their parents neither paid attention if they had attended the Quranic lesson at madrassa properly nor were concerned if they had revised the lesson at home. As a result, the respondents were discouraged from learning the Quran properly.

\subsubsection{Abandoning Quranic learning for a certain period}

Responses from 16 male and 9 female participants indicated that stopping the learning of Quran for a certain period also made it difficult for them to learn the Quran properly. The reasons for stopping include the sudden loss of interest in coming to madrassa and having to leave the madrassa without completing the Quranic learning. As a result, the respondents failed to properly acquire the knowledge of Quran despite receiving the lessons at the madrassa for a certain period.

\subsection{Currently interested in learning the Quran}

Based on the responses, 5 out of 20 male and 17 out of 20 female respondents expressed their interest in learning the Quran. Notably, females were more interested in learning than males. The following are the reasons that encourage the female respondents to take up the learning of Quran at middle-age.

- Self-awareness that one should involves oneself in spiritual activities.

- The desire to perform the prayers properly.

- Awareness that in order to teach the Quran to their children, they must also learn the Quran.

- Fear of the Hereafter.

This study also uncovered the reasons for not being able to learn the Quran, which are presented in the following sections.

\subsection{Factors that hinder learning of the Quran}

Although, all respondents expressed their interest in learning the Quran, there are some factors identified, which hinder the learning of Quran among middle-aged people. These factors are discussed in the following subsections.

\subsubsection{Very few people come forward to teach the Quran to middle-aged people}

Responses from 15 female and 5 male participants mentioned that there is limited number of teacher who can teach Quran to the middle-aged people. The analysis demonstrated that most of the participants who are interested in learning the Quran agreed with the statement. While there are many "Alims" and "Alimas" who offer to teach the Quran to children, there is only few who are offer Quranic lesson to middle-aged people. At the same time, there are very few "Alims" and "Alimas" who explain the importance of reciting the Quran to the middle-aged people. This is partly due to the mentality among the "Alims" and "Alimas", who think that it is difficult to teach the Quran to middle-aged people. However, they failed to realize that the Prophet (PBUH) had reached the age of 40 when the Quran was first revealed to him (Mubassar Siyah Melo). If teaching the Quran to the middle-aged people is difficult, then it would not have been possible for Muhammad (PBUH) to learn and spread the Quran when it was first revealed to him at that age. In addition, if it is only easy to teach the Quran to literate society, Jibreel would not had been compelled by Allah to teach the Quran to Mohammed (PBUH). On another note, when the Islamic teaching from the Quran was spread around, the majority of those who embraced the teaching were middle-aged people, with only few exceptions being children. It should be noted that 
Muhammad (PBUH) taught the Quran to people, who were mostly middle-aged. This proves that the mentality of the "Alims" and "Alimas that teaching Quran to the middle-aged people is very difficult is wrong.

4.4.2 There is no madrassa lesson created exclusively for middle-aged people as there are for children

Responses from 15 out of 17 males and 2 out of 5 females who are interested in learning the Quran highlighted that there is no madrassa lesson created exclusively for middle-aged people to learn the Quran as there are for children. Many "Alims" and "Alimas" come forward to teach the Quran to children, some even provide homebased learning. In addition, a number of programs are being implemented by the madrassas to teach Quran to the children, while there is none for the middle-aged people.

During the time when sufferings and atrocities were being inflicted on those who accepted Islam in the Prophet's time in Mecca, the Arkam (Rali) made it clear about Islamic teachings in their home, and arrangement was made and guidance provided for people to learn the Quran. It is regarded as the first madrassa in Islamic history (Rafiq Saman, 2013). In addition, after the migration to Madinah, the madrassa functioned as a place to teach the Quran in peace without any threat (Imamuddin SM, 1984). Compared to the Prophet's time, there is relatively no barrier that should prevent the teaching of Quran in Sri Lanka. Although living as a minority, the environment is conducive enough for children to learn the Quran in madrassa. Therefore, there is a need to find out the reasons that prevent arrangements for the middle-aged people to learn Quran at madrassa from being made.

\subsubsection{Spending more time caring for family and house hold working}

Responses from 12 female participants expressed their agreement that devoting a lot of their time caring for the family is one of the factors hampering their learning of Quran. Responsibilities such as that of a husband who needs to work, children who need to commit to homework from school are important factor that affecting the quality of Quran learning. Responsibilities limit the time and opportunity to learn, despite the great desire to learn the Quran. Responses from 4 out of 5 male participants expressed how working limit their genuine interest in learning the Quran. However, these men have an obligation to support their families and therefore, required to work for long hours in order to do so. Therefore, men who spend their time working from morning to evening find it difficulty devote their time to learning the Quran. However, there is no history of female or male Sahabah considering this as a major obstacle to learning the Quran. No matter how many obstacles were encountered, the teaching of the Quran was considered the greatest ibadah. Omar' sister learned the Quran even when Omar was hostile toward Islam; but women nowadays regard housework as barrier in learning the Quran, which is trivial as compared to what Omar's sister had to face. Other female Sahabah were also reportedly eager to learn Islam and understand the Quran. The Prophet (PBUH) also taught Islam to female in way that was beautiful like nothing before. In addition, although the Sahabah were working as laborers, they did not fail to spend their time learning Islam and understanding the Quran. On the other hand, Abu Bakr and 'Umar (RA) who were a great merchant at the time, did their business while spending time learning Islam and the Quran. People like 'Umar (RA) organized time by alternating the day for doing business and learning Islam and the Quran. Therefore, commitment to household chores and work cannot be taken as a barrier to learning the Quran.

\subsubsection{When it comes to learning the Quran, some people joke about it and look at it from a humorous perspective.}

There was 11 out of 17 female and 3 out of 5 male participants who agreed that being teased and made into a joke for wanting to learn to learn Quran at their age hinder them from actually learning the Quran. Do parents with children who are attending or already graduating from the madrassa would actually want to learn Quran at this age? Many people regard this as a prank. Sometimes, even their children observe and talk about it from a humorous point of view. The respondents found that the situation prevents them from actually learning the Quran even though they are interested in the lesson. However, it is written in history that many Sahabah, regardless of age, came to Abdullah ibn Abbas (RA) to learn the interpretation of the Quran; the Prophet (PBUH) endorsed the Quranic interpretation by Abdullah ibn Abbas (RA).

4.4.5 Shyness

Responses from 9 out of 17 female participants indicated that shyness is a barrier to learning the Quran at their age, despite the desire to take up the lesson. The respondents remarked that they find it shameful to learn the Quran considering their age and the environment they are surrounded with. Thinking about the perception of others have prevented them from actually learning the Quran. However, it is important to note that no Sahabah had ever felt ashamed to learn the Quran even as they were getting older.

\section{Conclusion}

There several reasons identified for people not going to an early childhood Quran learning at madrassa: lack of understanding on the importance of Quran; hatred toward the "Alims" at the time; lack of proper teaching of the rules in reciting the Quran; and failure to teach the Quran with proper guidance. Such are the reasons for not being able to recite the Quran properly when reaching middle age, even despite attending the madrassa at a young age. Currently, female are more interested in studying the Quran than male. In other words, 17 out of 20 
female are interested in learning the Quran. Factors such as lack of qualified teacher who is willing to teach the Quran to the middle-aged people and the shame among them have been identified as the most important challenges that are currently hinder the learning of Quran among this group. Furthermore, females find it difficult to learn the Quran as there is limited number of teacher who is willing to teach the Quran properly and lack of programs at madrassa that exclusively organized for middle-aged people to learn the Quran.

\section{Recommendations}

1. Many of the difficulties faced by people studying the Quran at madrassa in the early days have not been adequately taught. However, their current desire in learning is appreciated.

2. The Quran lessons should be made available to the middle-aged people in the same way as it is made available for children and the young generation. Every local madrassa's administrator in the community should be made aware of this need.

3. "Alims" and "Alimas" who are graduated from Arab colleges should come forward to teach the Quran to the middle-aged people.

\section{References}

Maimun Aqsha Lubis., Rosseni Din . (2011). Challenges faced by teachers in teaching Quranic tarannum. World Applied Sciences Journal 14 (Special Issue of Innovation and Pedagogy for Diverse Learners), 40-43.

Mohd Aderi., Ab Halim Tamuri., Khadijah Abd. Razak. \& Suhid Asmavati. (2014). The study of Quranic Teaching and Learning: United Kingdom Experience. Mediterranean Journal of Social Sciences, 313-317.

Mohn Aderi Che Noh, Katni, Yaumil Hatoya, Syarifan Nurjan \& Rohmadi . (2020). Examining Teaching And Learning Of Quran: Empirical Research Of Islamic School Of Ma'arif Al Mukarom Ponorogo East Java Indonesia. Journal of critical reviews, 698-701.

Nur Hannah Saari., Cila Umat. \& Kamarul Shukri Mat Teh. (2012). Factors Affecting the Learning of the Holy Quran among Severely and Profoundly Hearing-Impaired Children with a Cochlear Implant. IOSR Journal of Humanities and Social Science, 85-92.

Imamuddin. S. M. (1984).Mosque as a center of education in the early middle ages. Journal of Islamic Studies, 159-17.

Tedi Supriyadi., J. Julia . (2018). The Problem of Students in Reading the Quran: A Reflective-Critical Treatment through Action Research. International Journal of Instruction, 311-326. 